\title{
Assessment of Climate Variability in the Niger Delta Region of Nigeria
}

\author{
Kemela Barakumo* and Phoebe Atafo \\ Department of Photogrammetry and Remote Sensing (PRS), African Regional Institute for Geospatial Information \\ Science and Technology (AFRIGIST) formerly RECTAS, Nigeria \\ Email: bkemela2630@gmail.com
}

\begin{abstract}
This study investigated the variability of climate over the Niger Delta Region (NDR) focusing on the indicators of land use/land cover, land surface temperature (LST) and rainfall. Previous climate studies covered parts of the NDR; states and local areas, and these studies only quantified the amount of rainfall or air temperature separately. Hence, this study used a holistic approach. Rainfall and remotely sensed Landsat imageries (TM, ETM+ and OLI) for the period (1986-2018) were acquired and analyzed for land use/cover and obtained 97.6\%, 98.8\% and 99.8\% accuracies landuse/cover for 1986, 2001 and 2017 respectively; $27{ }^{\circ} \mathrm{C}, 29{ }^{\circ} \mathrm{C}$ and $31^{\circ} \mathrm{C}$ was obtained as fluxes in surface temperature for 1986, 2001 and 2017 respectively. Results for rainfall variability from the interpolated maps showed a general trend for the study period. First, it was found that rainfall in terms of amount varied and increased within the study period (1985-2014) across the NDR. To further validate the variability of rainfall, the Annual Rainfall Anomaly Index (RAI) was further calculated and analyzed for frequency and intensity of the dry and rainy years in the study area and found that the area within the period of study recorded more positive anomaly (rainy years) than negative anomaly (dry years). It was established also in this study that there is a relationship between different land use/land cover categories, LST and rainfall. This was found in the correlation analysis results obtained amongst the three indicators, built up area had strong positive correlation with those of rainfall and temperature $(0.78$ and $0.75 \%$ ) respectively. See figure 20 and 21.
\end{abstract}

Keywords: Rainfall, temperature, land-use, land-cover, anomaly-index

\section{Introduction}

Variability of climate plays an important part in determining the conditions in which living organisms function in a geographical setting. The issues of variations in climate have been due to persistent increase in global temperatures and other weather conditions. Such as drastic changes in rainfall regimes, pressure belt etc., thus have been of major socio-economic and environmental concern to many nations especially those within the tropics where the impact is likely to be more (Ibitolu et al, 2014). Temperature, rainfall, wind, air pressure, cloud and relative humidity changes over a long period are used in determining the climate variability of a geographical setting, thus making their study significant. In this study changes in rainfall, land surface temperature land use land cover are the elements of concern to assess and determine climate variability.

Rainfall variability studies over time have been either areal or temporal. Areal variability is the variation of rainfall condition over space for a specific period of time, while the latter is the variation of rainfall at a given location over time. Rainfall is a critical component of water and energy cycles. It is a critical source of water for water supply, agriculture, natural ecosystems, hydroelectric power, and industry and is central to issues of drought, flood, and disease hazards. Rainfall is one of the substantial weather indicators of climate change (Stringer, 1995; Bello, 1992). On the concept of rainfall as a factor of climate change (Farmer and Wigley, 1985) stated thus; if the fluctuations in rainfall records persisted for a long time and were, furthermore, statistically significant, then we might say, there had been a climatic change based on such rainfall record. The changes in rainfall regimes have a direct relationship with the hotness and coldness of a place (temperature).

Land surface temperature (LST) is an important climatic factor in both environmental and climate studies because, Land surface temperature (LST) is an essential parameter in the physics of land surface 
processes: it plays a key role in the energy and water transfers between the ground and the atmosphere. LST is controlled by solar radiation and the land-atmosphere heat exchange. Therefore, its spatial and temporal distributions reflect not only the variations of climate factors but also the land surface characteristics. An in-depth understanding of the spatial and temporal variations of LST is important to a range of research fields, including climate, vegetation, and hydrology Jin etal 1997, Manzo-Delgado etal, 2013 cited in Yongming etal, 2013.

LST represents the temperature recorded at the interface between the earth surface and the immediate atmosphere (Valiente, 2009) cited in (Ibitolu et al 2014), and is thus a measure of how hot the land surface at a particular location feels to touch. The LST is important in climatology as it has a direct impact on air temperature and it is also one of the main parameters in the underlying physics of land surface processes (Serban and Maftei, 2011; Dousset and Gourmelon, 2003) cited in (Ibitolu et al, 2014).

On the other hand, the land use practices and patterns equally affects the elements of weather that determine climate; thus any negative outcome serve as bottle-neck to the attainment of the SDG's (Sustainable Development Goals) 2030 agenda. Of note are (agenda 13, 14 and 15) which centers on climate change and its impacts, sustainable use of the ocean, seas and marine resources for sustainable development and sustainable use of terrestrial ecosystems, sustainably manage forests and biodiversity loss UN (2015).

The Niger Delta Region in recent time have been witnessing alternating changes in rainfall, land surface temperature rises and land cover changes; and these changes are partly attributed to climate change impacts resulting to extensive damages and loss of lives (Ituen, and Alonge, 2009; Ologunorisa and Tersoo, 2006; Udosen, 2012; Isikwue et al, 2013; Mathew et al, 2013; Okoro et al, 2014; Igweze et al, 2014; Ibitolu et al, 2014; and Egor et al, 2015).

Climatic Variability denotes the inherent dynamic nature of the climate on various temporal scales. Such temporal scale variations could be monthly, seasonal, annual, decadal, periodic, quasi-periodic or non-periodic (Akpodiogaga and Odjugo, 2010). Variation in climate is a product of either natural (biogeographical) and human activities (anthropogenic) processes. The human factors have been proven to be responsible for the ongoing unequivocal climate change and global warming (IPCC, 2007).

Variations on climate in the Niger Delta Region has been attributed more to anthropogenic factors (gas flaring and socio-economic activities of urbanization) leading to loss of biodiversity which have left the vegetal cover bare resulting in excess of carbon in the atmosphere. This biodiversity loss has led to overheating of the atmosphere and rise in temperature; thus resulting in excessive evaporation of the sea and nearby water bodies; this results to high spatio-temporal variability of rainfall which births environmental problems (Ituen, and Alonge, 2009; Ologunorisa and Tersoo, 2006; Udosen, 2012; Isikwue et al, 2013; Mathew et al, 2013; Okoro et al, 2014; Igweze et al, 2014 and Egor et al, 2015).

The quest and strive toward industrialization, technological innovations and the drive to modernism has resulted to modification and change in land use and land cover in a geographical setting thus serving as variable conditions that intensify hazards over an area leading to changes in the natural environmets of such settings (Effiong, 2011; Mmom and Nwagwu, 2013; Aderoju, 2014; Odjugo et al, 2015; Ejemeyovwi, 2015; Anieka and Ubom, 2016, Bariweni and Amukali, 2017); thus the foregoing literature indicates that previous climate studies covered parts of the Niger Delta Region; states and local area, and these studies only quantify the amount of rainfall (Akinsanola\&Ogunjobi, 2014; Igweze et al , 2014), some other authors studied climate change with regard to air and or land surface temperature separately though not for the whole Niger Delta Region (Ibitolu et al, 2014).

It appears that regional assessment of climate change considering rainfall, land surface temperature and land use/cover is rarely studied. Hence, this study used a holistic approach, a combination of multiple indicators of climate change (land use/land cover changes, land surface temperature and rainfall) using remote sensing and GIS techniques to test for variations in climate over the Niger Delta Region. 


\section{Materials and Methods}

\subsection{Types and Sources of Data}

This study used primary and secondary data. Thus the primary data included GPS ground truth point data to reference points of the rainfall data and also ground reference points for the land use land cover changes (supervised classification) table 1. Landsat imageries for 3 epochs (1986), (2001) and (2017) from the archives of the United States Geological Survey (USGS) were used as secondary data. From this data sets; land surface temperature and land use/land cover information were extracted after processing. Also part of the secondary data used was rainfall data (1985-2014) from 11 existing rainfall stations (Akure, Benin, Warri, Asaba, Yenagoa, Port Harcourt, Owerri, Uyo, Calabar, Ogoja and Ikom) across the NDR. The rainfall data was retrieved from the archives of the Nigerian Meteorological Agency (NIMET) and was used for rainfall variability assessment.

Table 1. Data types and sources

\begin{tabular}{lllll}
\hline Data Type & Source & Year & Resolution & Purpose \\
\hline Rainfall & Nigerian Meteorological Agency & $1985-2014$ & - & Rainfall Variability \\
Landsat 4-5 (Path/Row) & www.earthexplorer.usgs.gov & 1986 & $30 \times 30 \mathrm{~m}$ & LULC \& LST \\
Landsat 7 ETM+ (Path/Row) & www.earthexplorer.usgs.gov & 2001 & $30 \times 30 \mathrm{~m}$ & LULC \& LST \\
Landsat 8 OLI (Path/Row) & www.earthexplorer.usgs.gov & 2017 & $30 \times 30 \mathrm{~m}$ & LULC \& LST \\
GPS Coordinate & Field Work & 2018 & - & Ground Truth Data \\
& & & & for Change Detection \\
\hline
\end{tabular}

Source: Compiled by author, 2018

\subsection{Methods}

\subsubsection{Land use/land cover assessment}

The Landsat imageries (Thematic Mapper TM, Enhanced Thematic Mapper ETM+ and Operational Land Imager OLI) were processed for change detection (from the data type used as outlined in table 3.1) within the study period under consideration for 1986, 2001 and 2017 over the Niger Delta Region NDR. The Anderson (1971) Classification Scheme Level I was adopted for this purpose. This is because the study area covers a wide area (inter-state/regional coverage), thus making this scheme suitable for this study see Table 2. Supervised algorithm (Maximum Likelihood) was used; This algorithm assumes that the estimated probabilities are equal for all classes and the histograms of the input bands have normal distributions in order to get a precise outcome. This method considers mean, variances and the variability in brightness values of each class given as a training set.

Table 2. Classification scheme

\begin{tabular}{ll}
\hline Land Use/Land Cover & Description \\
\hline Built-Up & All residential, commercial and industrial areas (villages, settlements, transportation \\
& infrastructures) \\
Waterbody & River, permanent open water, lakes, ponds, canals, reservoirs. \\
Vegetation & Trees, forests, old vegetated lands \\
Bare-land & Grassland, cultivated areas, earth and sand lands, infillings and solid waste landfills. \\
\hline
\end{tabular}

Source: Anderson et al, (1971)

\subsubsection{Land surface temperature assessment}

The thermal bands (band 6 in Landsat 4-5 and band 10-11 in Landsat OLI) were extracted to get the land surface temperature statistics. This was done by first converting their Digital Numbers (DNs) to Top of the Atmosphere (TOA) radiance values which were in turn converted to brightness temperature in Kelvin $(\mathrm{K})$, then to degrees Celsius $\left({ }^{\circ} \mathrm{C}\right)$ as final output to determine the Land Surface 
Temperature(LST). For the Landsat OLI, the Land Surface Emissivity (LSE) and Normalized Difference Vegetation Index (NDVI) was further calculated and converted from degrees' kelvin (0K) to degrees Celsius $\left({ }^{\circ} \mathrm{C}\right)$ using GIS.

\subsubsection{Rainfall data analysis}

To analyze the rainfall data, the study employed basic statistical techniques such as computation of totals and mean (annual mean 1985-2014) to give meaning to the rainfall data, to have a fair look of the general pattern and characteristic of rainfall in the region.

Mean annual precipitation was then calculated for the periods 1985-1987, 2000-2002, 2012-2014 and 1985-2014 in Microsoft Excel for interpolation. The rainfall values were imported as dbf files into a GIS interface for interpolation analysis using Inverse Distance Weighting (IDW) algorithm. The IDW has the advantage that it is easy to define and therefore easy to understand the results because the interpolating point is most influenced by nearby points and less by the more distant points: the principle of spatial auto-correlation or Tobler's First Law of Geography, Burrough and McDonnell, (1998).

This study equally tested for frequency and intensity of dry and rainy years that is; increases and reductions in rainfall. The Van Rooy's Rainfall Anomaly Index was employed to check for trend (Van Rooy, 1965) table 3. RAI, developed and firstly used by Rooy (1965) and adapted by Freitas (2005), constitutes the following equations:

where:

$$
\begin{aligned}
\text { RAI } & =3\left(\begin{array}{l}
N-\hat{N} \\
\dot{M}-\hat{N}
\end{array}\right) \text { For positive anomalies } \\
\text { RAI } & =-3\left(\begin{array}{l}
N-\hat{N} \\
\ddot{X}-\hat{N}
\end{array}\right) \text { For negative anomalies }
\end{aligned}
$$

$\mathrm{N}=$ current monthly/yearly rainfall, in order words, of the month/year when RAI will be generated in $(\mathrm{mm})$;

$\hat{N}=$ monthly/yearly average rainfall of the historical series $(\mathrm{mm})$

$\hat{M}=$ average of the ten highest monthly/yearly precipitations of the historical series (mm);

$\ddot{\mathrm{X}}=$ average of the ten lowest monthly/ yearly precipitations of the historical

Table 3. Classification of rainfall anomaly index intensity

\begin{tabular}{lll}
\hline \multirow{2}{*}{ Rainfall Anomaly Index (RAI) } & RAI Range & Classification \\
\cline { 2 - 3 } & Above 4 & Extremely Humid \\
& 2 to 4 & Very Humid \\
0 to 2 & Humid \\
-2 to 0 & Dry \\
-4 to -2 & Very Dry \\
Below -4 & Extremely Dry \\
\hline
\end{tabular}

Source: Freitas (2005) adapted by Araújo et al. (2009)

\subsubsection{The link between the different land use/land cover categories, land surface temperature and rainfall}

To establish relationship between two land use/land cover categories; (vegetation and built-up land, land surface temperature and rainfall) were used to test for correlation. The correlation and regression analysis in Microsoft Excel (data analysis tool) was used to quantify the measure of strength of association between variables (e.g., between an independent and a dependent variable or between two independent variables). The sample correlation coefficient, denoted r, ranges between -1 and +1 and quantifies the direction and strength of the linear association between the two variables. Thus, the following regression equation applies;

where

$$
r=\frac{\sum\left(x-x^{\prime}\right)\left(y-y^{\prime}\right)}{\sqrt{\sum\left(x-x^{\prime}\right) 2 \sum\left(y-y^{\prime}\right) 2}}
$$

$\mathrm{n}=$ Quantity of information

$\Sigma \mathrm{x}=$ Total of the first variable value

$\Sigma \mathrm{y}=$ Total of the second variable value

$\Sigma x y=$ Sum of the product of first \& second value 
$\Sigma \mathrm{x}^{2}=$ Sum of the squares of the first value

$\Sigma \mathrm{y}^{2}=$ Sum of the squares of the second value

On the other hand, regression is used to explain the relationship between one continuous dependent variable and an independent variable (s). The independent variables can be continuous or categorical.

Thus the simple linear regression equation as shown below;

where

$$
\mathrm{Y}_{\mathrm{i}}=\alpha+\beta \times \mathrm{X}_{\mathrm{i}}+\varepsilon_{\mathrm{i}}
$$

$\mathrm{Y}$ is the dependent variable

$\mathrm{X}$ is the independent (explanatory variable)

$\varepsilon$ is the random error term.

For this analysis, the dependent variables $(\mathrm{Y})$ are vegetation and built-up, and the independent $(\mathrm{X})$ variables include Land Surface Temperature and Rainfall. So each of the dependent variables (vegetation and built-up land) will be paired separately with those of the independent variables (LST and rainfall).

\section{Result and Discussion}

\subsection{Land Use and Land Cover of the Study Area between 1986 and 2017}

To achieve the objective of the land use land cover change over the study area, an object-oriented image analysis was carried out to generate the LULC maps. To justify quality, the generated images were further validated and quantified for classification accuracy assessment. The overall accuracies for the maps of 1986, 2001 and 2017 were $90.80 \%, 96.06 \%$ and $95.40 \%$ respectively. This is considered satisfactory for being up to the minimum accuracy threshold requirement of $85 \%$ (Eastman, 2000). The categories applicable to this study under the Anderson's level I classification scheme include; built-up land, Forest land, water-body, wet-land and bare-land. Classified land use is presented in figures 1, 2 and 3. The results detailed forest land as the dominant land cover occupying between $88 \%$ and $43 \%$, with water body having less than $3 \%$ as the least category (Table 4 ).

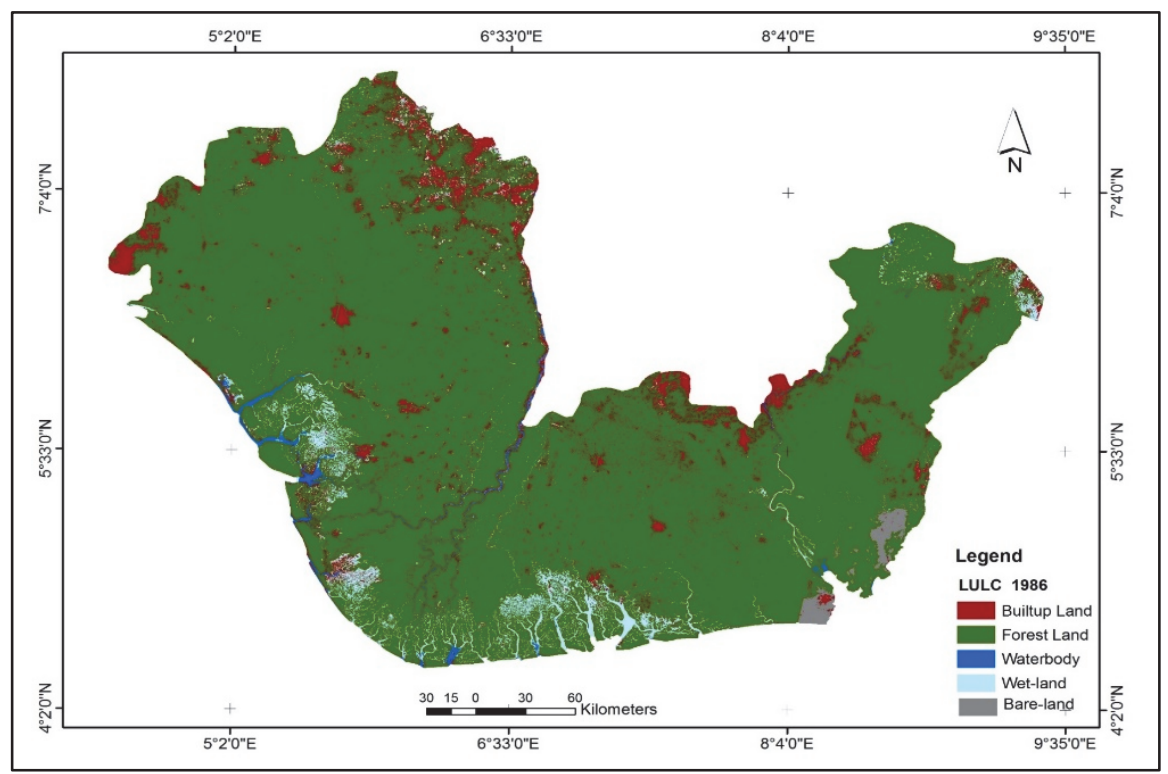

Figure 1. Land use land cover 1986 (Source: Author, 2018) 


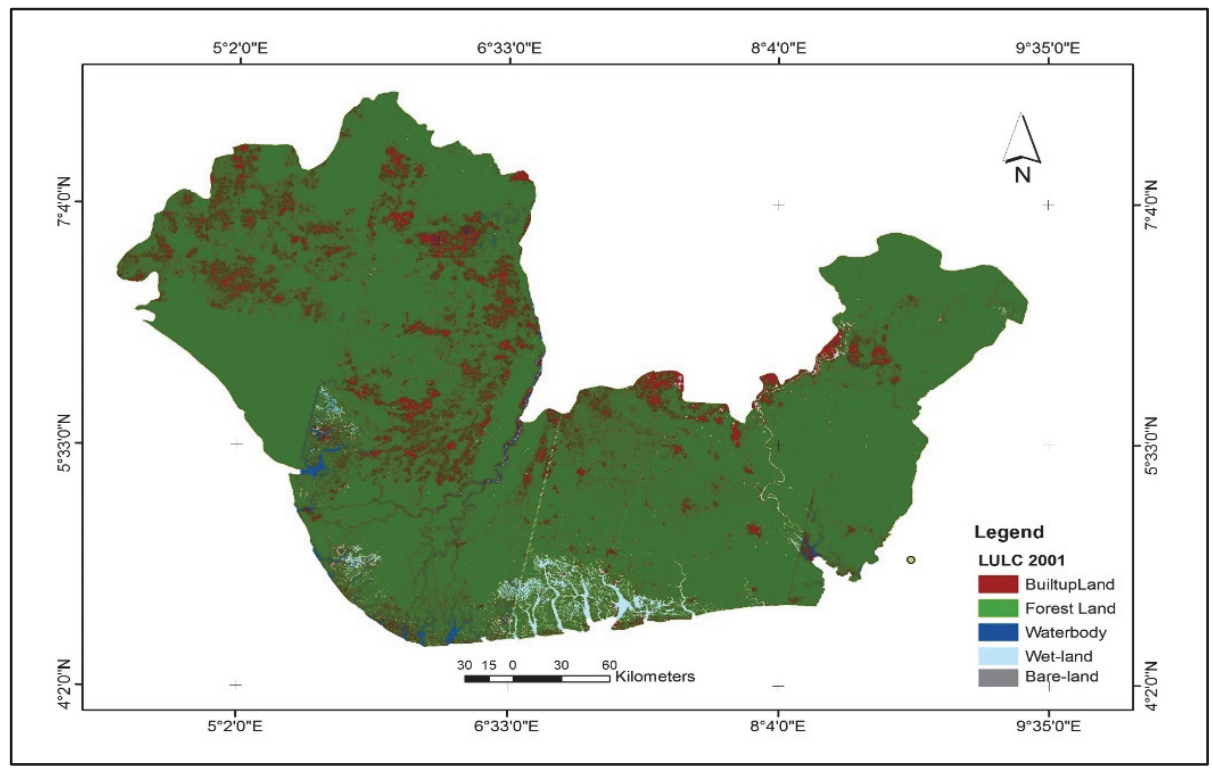

Figure 2. Land use land cover 2001 (Source: Author, 2018)

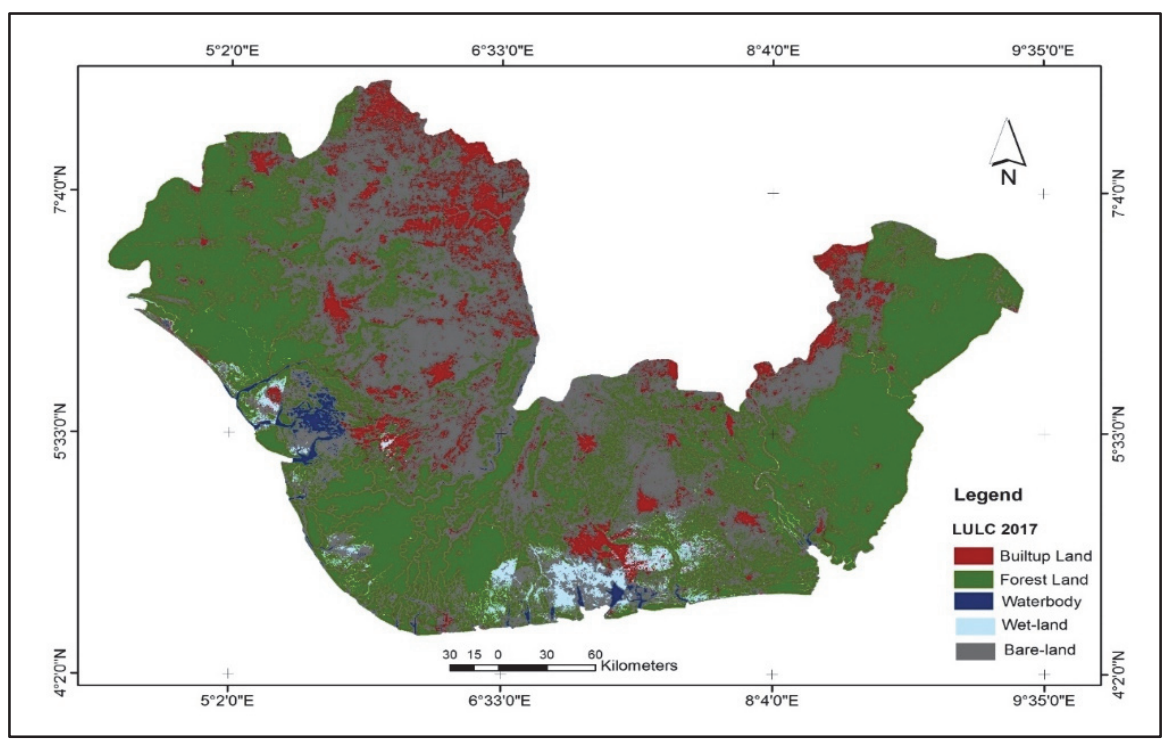

Figure 3. Land use land cover 2017 (Source: Author, 2018)

Table 4. Land class statistics 1986-2017

\begin{tabular}{lllllll}
\hline Category & $\mathbf{1 9 8 6}($ Sq. k) & Percentage & 2001 (Sq. k) & Percentage & 2017(Sq. k) & Percentage \\
\hline Builtup Land & $\mathbf{7 0 1 9 . 3 6}$ & $6 \%$ & $\mathbf{8 0 9 6 . 2 9}$ & $7 \%$ & $\mathbf{9 0 8 3 . 8 1}$ & $8 \%$ \\
Forest Land & $\mathbf{9 5 6 9 0 . 2 0}$ & $88 \%$ & $\mathbf{9 0 8 6 3 . 7 4}$ & $87 \%$ & $\mathbf{5 3 1 4 4 . 7 4}$ & $49 \%$ \\
Waterbody & $\mathbf{1 0 1 5 . 0 7}$ & $1 \%$ & $\mathbf{1 6 8 8 . 1 2}$ & $2 \%$ & $\mathbf{3 3 2 1 . 2 5}$ & $3 \%$ \\
Wetland & $\mathbf{3 8 5 6 . 8 2}$ & $4 \%$ & $\mathbf{1 6 8 8 . 1 2}$ & $2 \%$ & $\mathbf{3 5 4 6 . 0 1}$ & $3 \%$ \\
Bareland & $\mathbf{9 1 4 . 5 3}$ & $1 \%$ & $\mathbf{6 6 . 9 5}$ & $0 \%$ & $\mathbf{3 9 6 3 9 . 7 7}$ & $36 \%$ \\
Total & $\mathbf{1 0 8 4 9 6}$ & $100 \%$ & $\mathbf{1 0 8 7 3 6}$ & $100 \%$ & $\mathbf{1 0 8 7 3 6}$ & $100 \%$ \\
\hline
\end{tabular}

Source: Author, 2018 


\subsection{Land Surface Temperature Assessment}

The land surface temperature was assessed, the results showed persistent increases from 1986 through 2001 to 2017. The result showed temperature fluxes between $18{ }^{\circ} \mathrm{C}$ to $27^{\circ} \mathrm{C}$ for 1986 as minimum and maximum average temperatures, 2001 recorded $18{ }^{\circ} \mathrm{C}$ to $29{ }^{\circ} \mathrm{C}$ minimum and maximum average temperatures. For 2017 , higher temperature values of $19{ }^{\circ} \mathrm{C}$ to $31^{\circ} \mathrm{C}$ as minimum and maximum average temperature values were found table 5 .

Table 5. Land surface temperature averages

\begin{tabular}{lll}
\hline Period & Minimum Average & Maximum Average \\
\hline 1986 & $18{ }^{\circ} \mathrm{C}$ & $27{ }^{\circ} \mathrm{C}$ \\
2001 & $18{ }^{\circ} \mathrm{C}$ & $29{ }^{\circ} \mathrm{C}$ \\
2017 & $19{ }^{\circ} \mathrm{C}$ & $31^{\circ} \mathrm{C}$ \\
\hline
\end{tabular}

Source: Author 2018

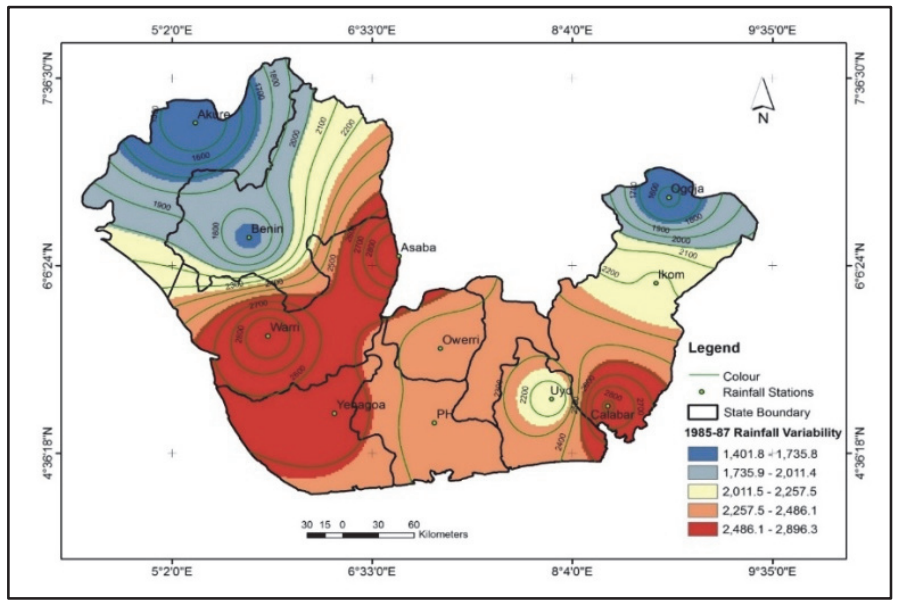

Figure 4. Rainfall between 1985-1987 (Source: Author, 2018)

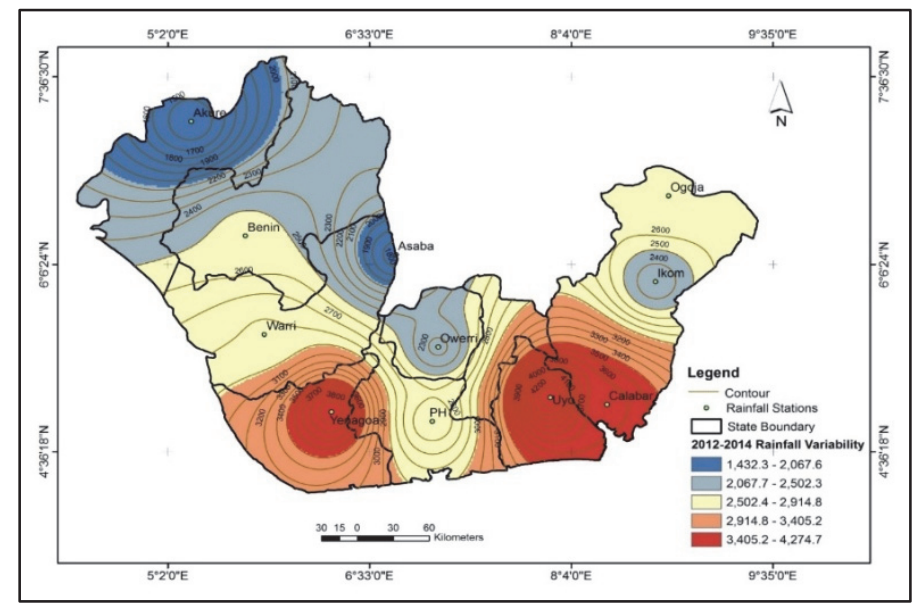

Figure 5. Rainfall between 2012-2014 (Source: Author, 2018) 


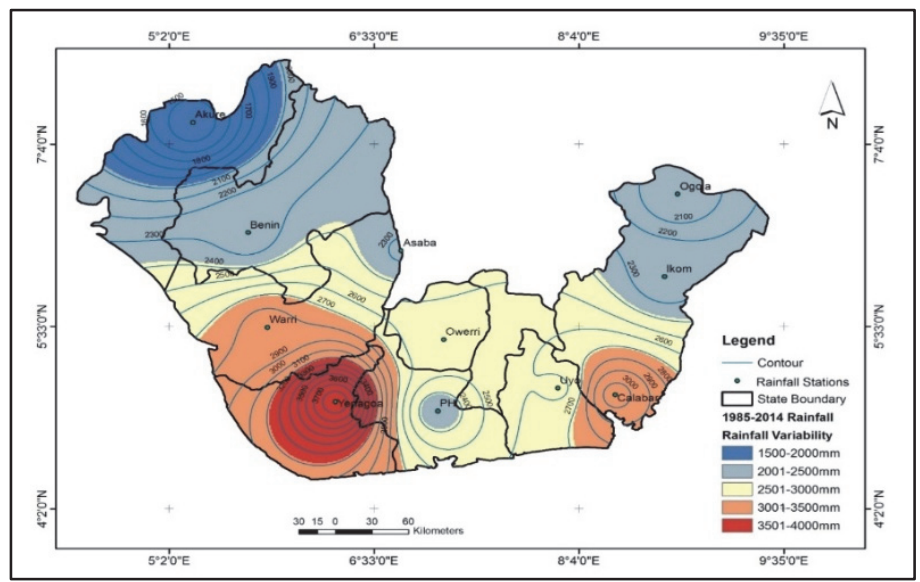

Figure 6. Rainfall between 1985-2014 (Source: Author, 2018)

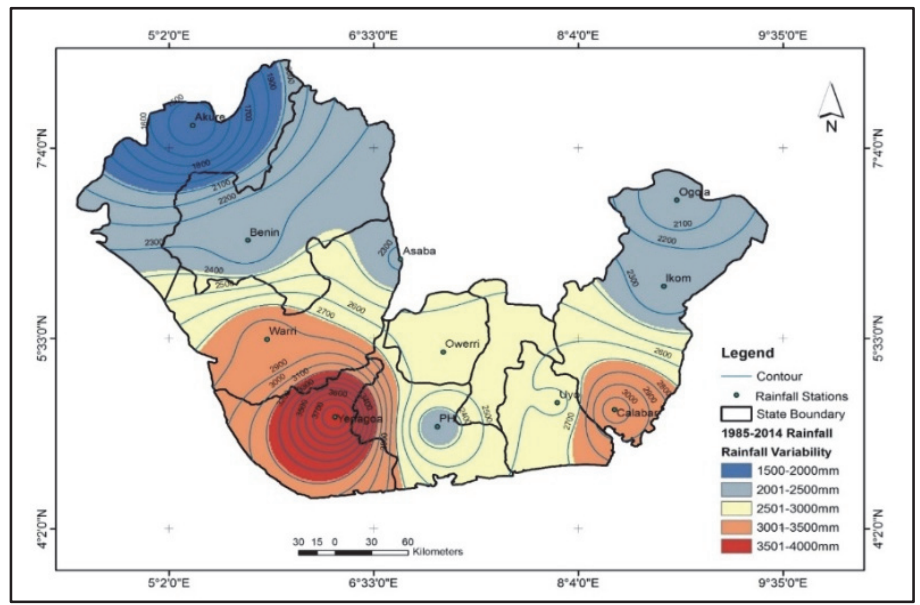

Figure 7. Rainfall between 1985-2014 (Source: Author, 2018)

\subsection{Rainfall Variability over the Study Area}

Rainfall for this study was considered in terms of annual mean amount and variability; both total amount and variability has been considered and assessed on annual and periodic basis (3 epochs; 19851987, 2000-2002 and 2012-2014). The average rainfall amount for each year within the study period (1985-2014) was also computed for in the NDR and mapped (Fig 4-8). From the interpolated maps, the pattern of rainfall showed a general trend for the study period. First, it was found that rainfall in terms of amount increased within the study period (1985-2014). Second, the latter years in the southern part of the region recorded consistent higher rainfall amount (above $3000 \mathrm{~mm} /$ annum) throughout the period of study. From here (the south parts) rainfall decreases to within $2000 \mathrm{~mm}$ and below in the south east and South Western parts as areas of moderately consistent rainfall. The north east and extreme north west portion were generally found to be areas with consistent low rainfall values (Fig. 4-7).

\subsection{Frequency Intensity of Dry and Rainy Years (1985 to 2014)}

To further validate the variability of the rainfall, the Annual Rainfall Anomaly Index (RAI) was calculated to analyze the frequency and intensity of the dry and rainy years in the study area. In addition, the monthly RAI was computed and calculated for the historical series (1985-2014) aiming to analyze the distribution of rainfall in the years of greatest anomaly and the obtained results were interpreted against the Freitas Classification scheme as shown in table 3. 
From the temporal and spatial distribution of rainfall in the NDR, the rainy season begins in the month of March and lasts until the month of September-October. Within this range, the precipitation is higher than the annual average. The month of September presented the highest precipitation value, over $3000 \mathrm{~mm}$ in most of the stations assessed within the study period, this month is more efficient in terms of precipitation in the Southern parts of the region, this is because it has a greater influence of the Intertropical Convergence Zone (ITCZ), which is important for the recharge of the river system. The drought years and the rainy years, during the period from 1985 to 2014, can be visualized by means of RAI (Figure 8-17), enabling to identify periods where these events were more intense and/or lasting.

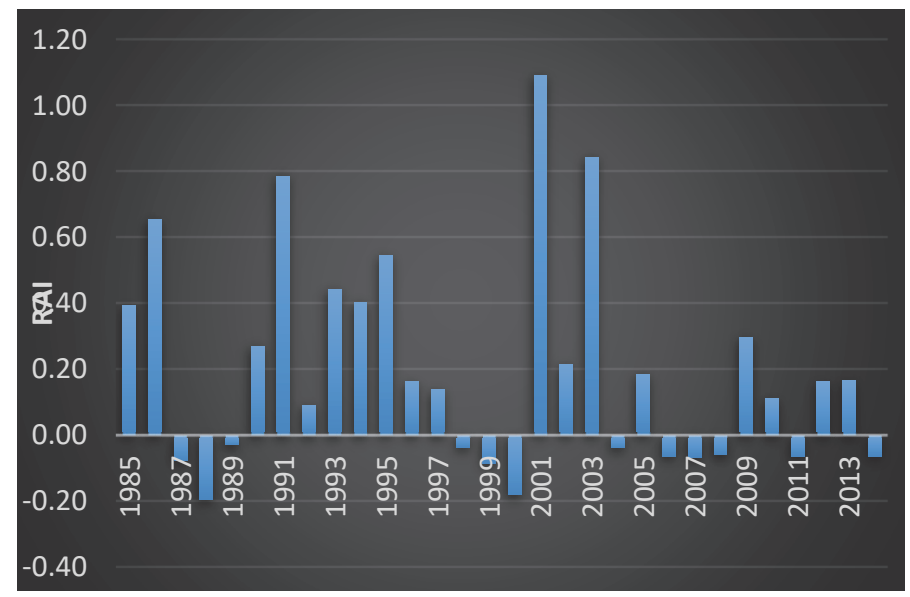

Figure 8. Akure RAI index

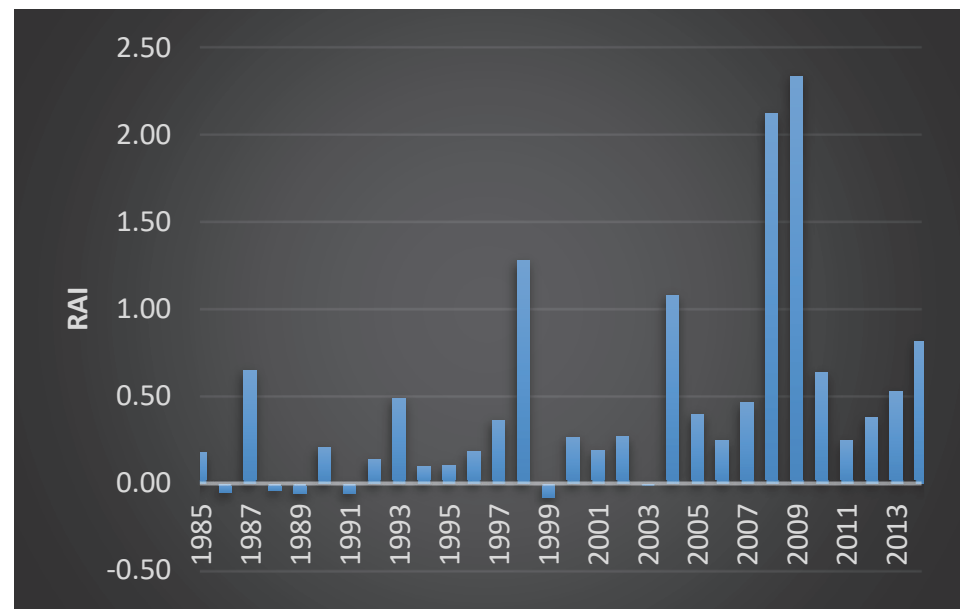

Figure 9. Owerri RAI index 


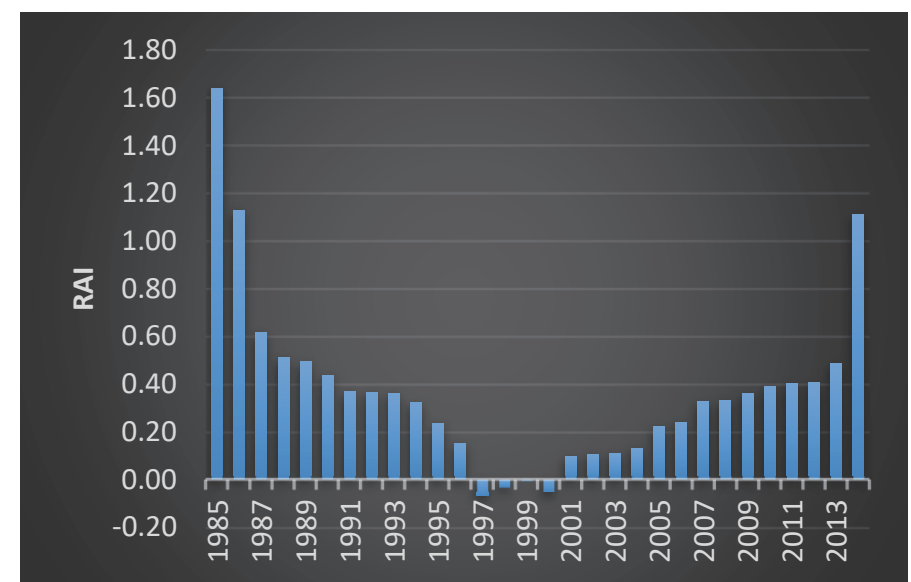

Figure 10. Benin RAI index

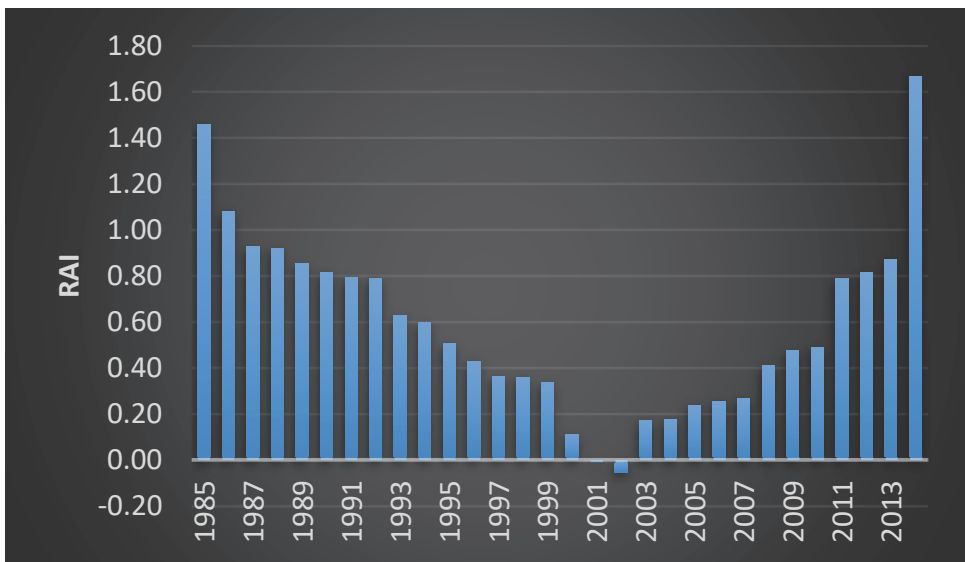

Figure 11. Ogoja RAI index

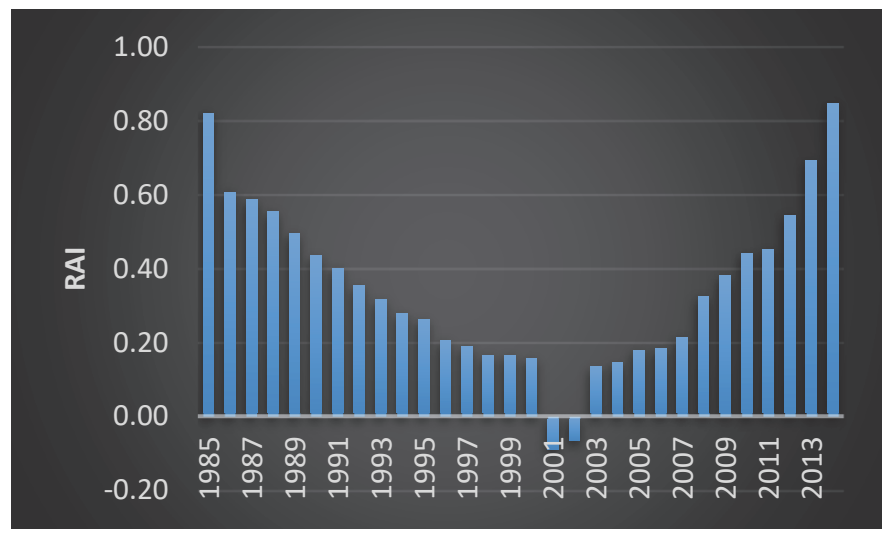

Figure 12. Calabar RAI index 


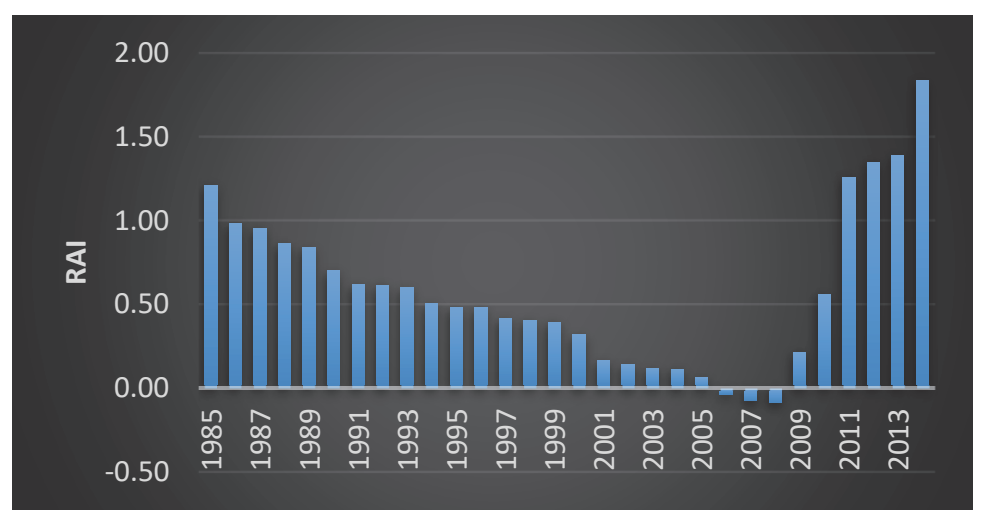

Figure 13. Uyo RAI index

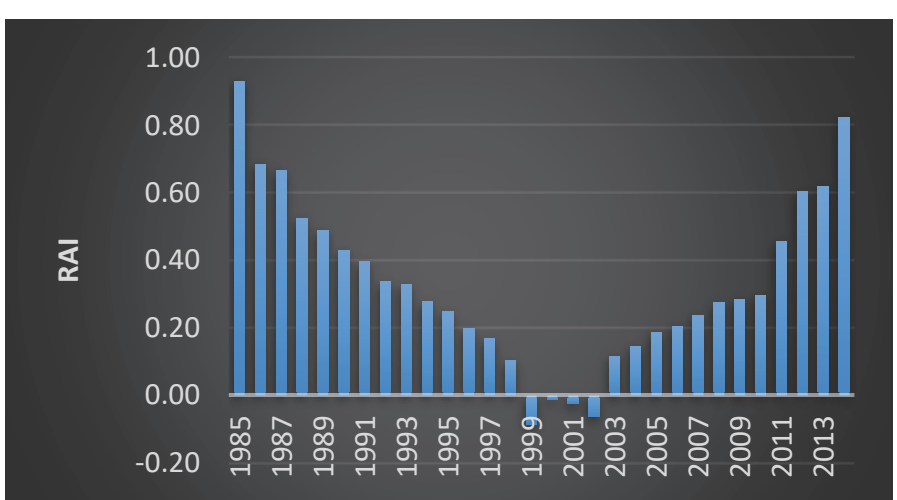

Figure 14. Port Harcourt RAI index

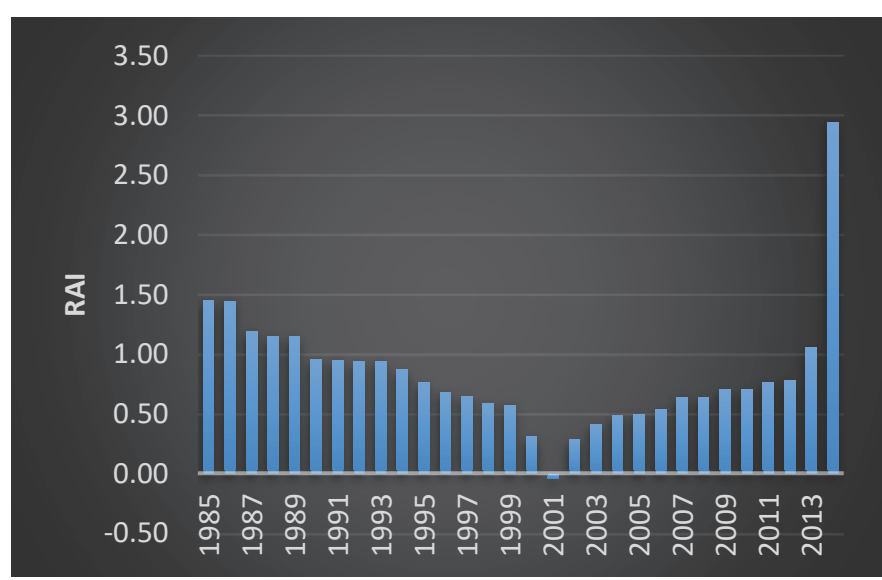

Figure 15. Asaba RAI index 


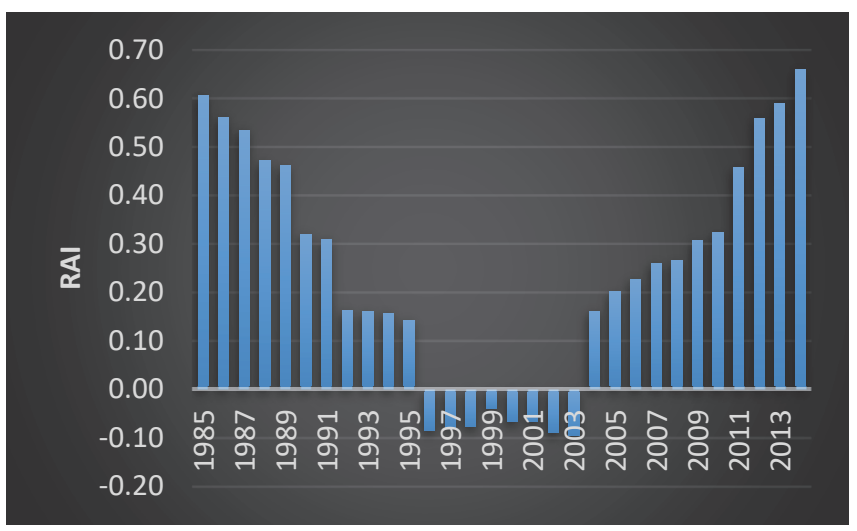

Figure 16. Warri RAI index

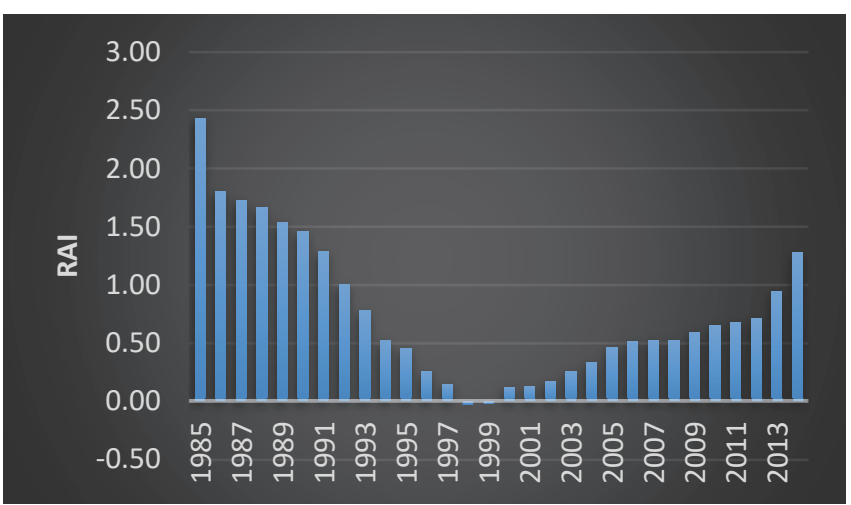

Figure 17. Yenagoa RAI index

The positive values observed in the figures above (figure 9-17) represent rainy or wet years and the negative values represent the dry years, with different degrees of intensity. Within the 30 years' period each across the 11 rainfall stations in the NDR (making a total of 330 years'), the study found occurrence of positive RAI values in 276 years, varying from very humid to humid, and 54 years with a negative RAI, varying between very dry and dry. In other words, there were more years of rainy than dry years within the period of study ((1985-2014). The periods that remained the longest with droughts were (Akure 1987 to 1989, 1998 to 2000, 2005 to 2008, 2011 and 2014); (Ikom 1995 to 2004); (Warri 1986 to 2003); (Owerri 1986, 1988 to 1989, 1991, 1999, 2003); these locations in the study area had years with the highest negative value, with a RAI of 0.0 values, classified as dry (table 3 ). The years of greatest positive value were (Asaba, 2014; Yenagoa 1985; Benin 1985; Owerri 2009 and Akure 2001), with an average RAI of 2.0 to 2.8 , being classified as very humid (table 3 ). Thus, the revelations above suggest one thing and that one thing is that climate change indicators have varied over time and these fluxes calls for concern.

\subsection{Relationship between Land Use/Land Cover, Land Surface Temperature and Rainfall}

To establish relationship between the two land use/land cover categories (Vegetation, Built-up), land surface temperature and rainfall. The correlation and regression analysis was used. Vegetation and builtup (dependent variables) was correlated and regressed against LST and rainfall (independent variables). The results reveal two kinds of relationship, first the category with strong correlation, Figure 20 (temperature and built-up land) and Figure 21 (rainfall and built-up land). The second category is the category with weak correlation Figure 19, (between temperature and vegetation). The study also found a strong negative correlation between vegetation and rainfall; as rainfall increases, vegetated land decreases over time (Figure 19). 
The study found a strong degree of association between the indicators of both rainfall and temperature, built-up land and land surface temperature within the period of study. That is as built up increases the climate indicators of rainfall and temperature increases likewise, amounting to a strong positive correlation ( 0.78 and 0.75 respectively) as shown in (Figure 20 and 21). The second category of association is the category with weak correlation, under which we have (vegetation and temperature). In this category, there is relationship but a weak relationship Figure 19 and 18.

This study in a nutshell found variation in land use/land cover, rainfall, land surface temperature as having persistent increase over the period of study and these variations have micro climatic implications. The Intergovernmental Panel on Climate Change predicts that the level of threats to forests and vegetation will increase in the 21st century; this is the case in the Niger Delta Region, the region has witnessed persistent decrease in vegetation corroborating with the findings of Okali and Eleri (2004). Rising temperatures, heavy rains, and humidity will render forests and vegetation more prone to many threats, including pests and diseases. Forests are vitally important as they soak up carbon dioxide, the main greenhouse gas responsible for global warming, and help regulate the world's climate. They are also home to countless plant and animal species.

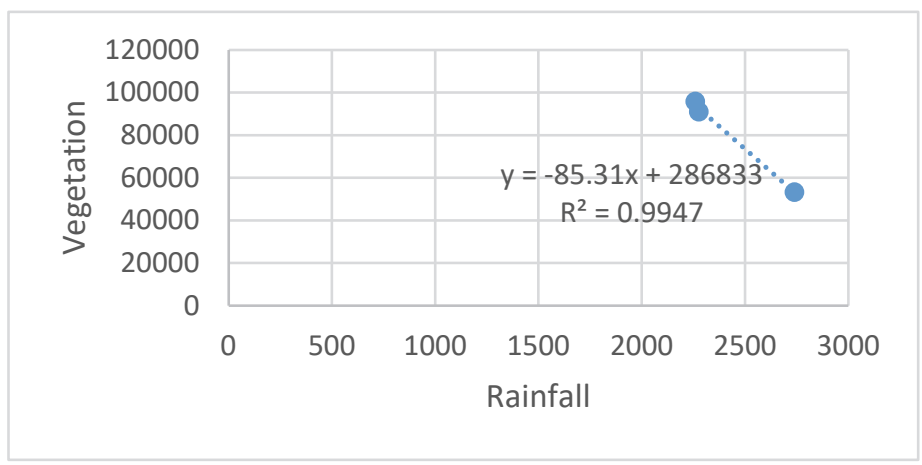

Figure 18. Rainfall \& vegetation strength/trendline

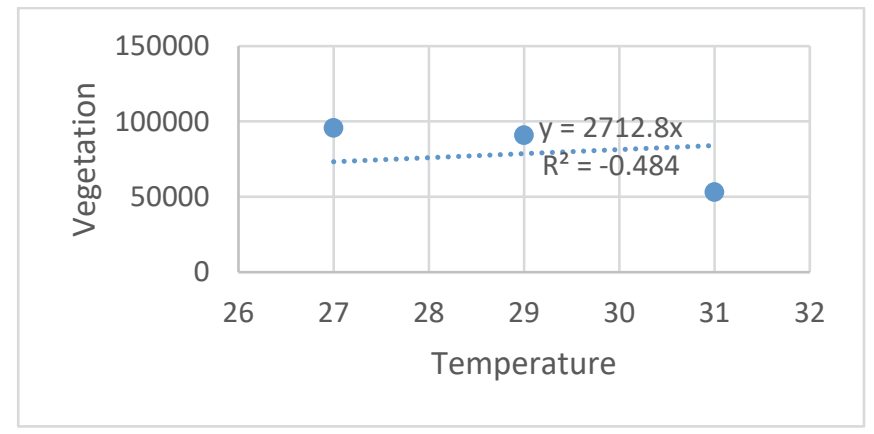

Figure 19. Temperature \& vegetation strength/trendline

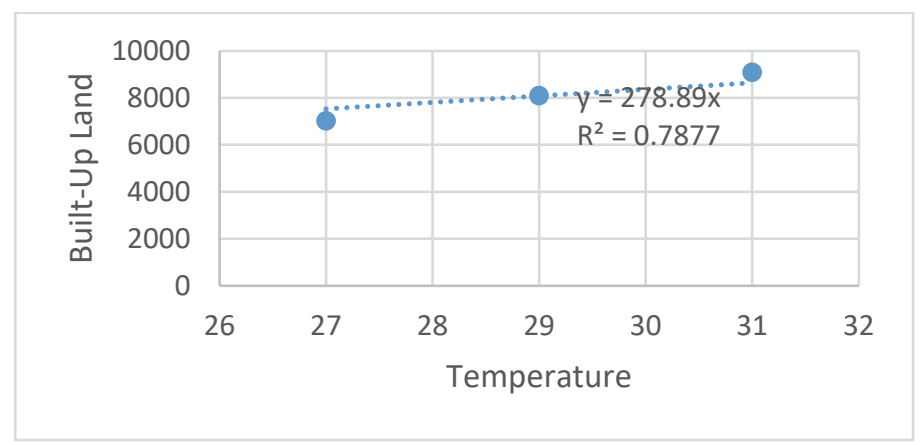


Figure 20. Temperature \& strength/trendline

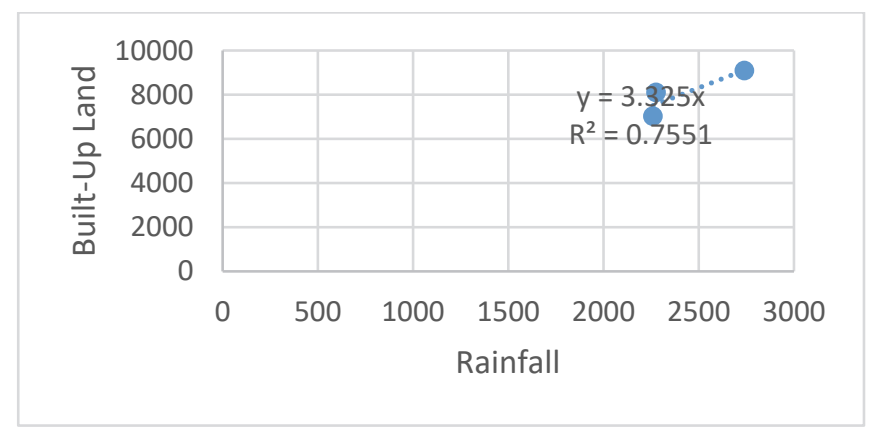

Figure 21. Rainfall \& builtup strength/trendline

In tropical forests such as the Niger Delta Region where there is abundant biodiversity, even modest levels of climate change can cause high levels of extinction. When large areas of forest are destroyed it is disastrous for the local species and communities that rely on them. There are variable conditions that intensify environmental hazards and degradation as a result of human occupance that are also evident in the Niger Delta Region that have led to vegetal cover changes in the region due to developmental activities which have led to rapid growth that also reduce surface intensity; for example, residential land use, roads, (Twumasi and Merem, 2006; Abbas, 2012; Onwuteaka, 2014 and Ejemeyovwi, 2015). State creation and the development of the oil industry have resulted in the emergence of new towns and subsequently increase in the spatial extent of built-up areas and development of infrastructure; all these have direct effect on $\mathrm{CO}_{2}$ emissions.

Dying trees emit their stores of carbon dioxide and methane, adding to atmospheric greenhouse gases and setting us on a course for runaway global warming leading to increases in coastal rainfall \& eventual rise in sea level. This persistent decrease in vegetation cover is also directly related to increases in the built-up land for this region as shown from our correlation analysis. changes in the land use/land cover affects global systems: atmosphere, climate, forests, sea levels and also a significant effect on localized places were such changes occur because of their global warming, loss of biodiversity and impact on human life. Thus, built-up land was found to be of increase over the past decades. This was also reported by the previous studies of Twumasi and Merem (2006), Onwuteaka (2014) and Ejemeyovwi (2015); these studies found increase in built-up land in the Niger Delta Region. The study also found extreme rainfall conditions (persistent increases) over the Niger Delta Region that makes it vulnerable to both flooding and draught. This was further confirmed from the results obtained from the Rainfall Anomaly Index (RAI) analysis conducted in this study, which reveal that the region has recorded more years of positive rainfall anomaly than negative. Previous studies of Mathew et al (2013), Okoro et al (2014), Akinsanola and Ogunjobi (2014) and Egor et al (2015) also found steady increase in rainfall over the past decades in the Niger Delta Region.

\section{Conclusion}

Previous climate studies covered parts of the Niger Delta Region; states and or local areas, thus studies only quantify the amount of rainfall and some other authors studied climate variability with regard to air and or land surface temperature separately though not for the whole Niger Delta Region. Thus warranted this holistic approach a combination of multiple indicators of climate change (land use /land cover changes, land surface temperature and rainfall variability) using remote sensing and GIS techniques to test for variations in these climate indicators over the last 30 years in the Niger Delta Region; (the knowledge gap in this study). The results showed a joint link between rainfall variability, land use changes and land surface temperature changes over the Niger Delta Region within the period of study. This was found in the correlation analysis results obtained amongst the three indicators, built up area had strong positive correlation with those of rainfall and temperature $(0.78$ and $0.75 \%)$ respectively. See figure 20 and 21. 


\section{References}

1. Aderoju, M. O., Okeke O., Nwadike, K. B., Eta, J., Onuoha, U. H, Ihenacho, M. N., \& Eshiet, R. (2014). Impact of Urban Land Use Change on Flood Events in Warri, Delta State. J. of Env. Sci., Toxicology and Food Technology 8(10) 2319-2402.

2. Akinsanola, A.A., \& Ogunjobi, K.O. (2014). Analysis of Rainfall and Temperature Variability over Nigeria. Glob. J. of Human-Soc. Sc. 14(3); 1-19.

3. Akpodiogaga, P. \& Odjugo, O., (2010). General Overview of Climate Change Impacts in Nigeria. J. of Hum. Ecol. 29(1): 47-55 (2010).

4. Anderson, J.R., Hardy, E.E., Raoch, J.T., \& Witmer R.E. (1971). A Land Use and Land Cover Classification System for Use with Remote Sensor Data. U S Geological Survey Circular 671, 12-14.

5. Aniekan, E., \& Okon, U. (2016). Spatio-Temporal Analysis of Land Use Land Cover Change Trends in AkwaIbom State Nigeria from 1986-106 Using Remote Sensing and GIS. Int. J. of Sci. and Research5(10)23197064 .

6. Bariweni, P.N., \& Amukali, O. (2017). Development \& Wetland Change in Yenagoa Metropolis, Bayelsa State, Nigeria (In Print).

7. Bello, N.J. (1998). Evidence of Climate change based on rainfall records in Nigeria. J. of Weather, 53 (12). 412 -418 .

8. Burrough, P.A. \& McDonnell, R.A., (1998). Principles of Geographical Information Systems. Oxford University Press, Oxford, 333 pp.

9. Egor, A. O., Osang, J. E., Uquetan, U. I., Emeruwa, C., Agbor, M. E. (2015). Inter-annual variability of rainfall in some states of Southern Nigeria. Int. J. of Sci. and Tech. Research 4(10), 2277-8616.

10. Ejemeyovwi, O. D. (2015). Change Detection in Land Use/Land Cover Mapping in Asaba, Niger Delta Between 1996 and 2015 (A Remote Sensing and GIS Approach). British J. of Environ. Sci. Vol. 3(3) 42-61.

11. Effiong, J. (2011). Changing Pattern of Land Use in the Calabar River Catchment, Southeastern Nigeria. J. of Sustainable Dev. 4(1).

12. Eastman, R.J. (2000). IDRISI 32 Guide to GIS Image Processing. Clark University, Worcester, M.A USA $1(109-142)$.

13. Farmer, G. \& Wigley, T.M.L. (1985). Climatic Trends for Tropical Africa. A research report for the Overseas Development Administration. 136 pp.

14. Ibitolu, H.A., Ogunjobi, K.O., Aderoju, M.O., Akinsanola, A.A., \& Daramola, M.T. (2014). Analysis of Climate on Land Surface Temperature and Vegetation Over Akure Using Geospatial Techniques. International Conference Proceedings of the Nigerian Meteorological Society, 9th- 13th November, 2014, Makurdi Nigeria.

15. Igweze, A.H., Amagoh, M.N., and Ashinze., A.N. (2014). Analysis of Rainfall Variations in the Niger Delta Region of Nigeria. J. of Env. Sc., Toxcol. and Food Tech.8(1)25-30

16. Isikwue, B.C.,Ameh, M.E., \& Uta,E.Y. (2013). Analysis of Rainfall Variability in Nigeria Using Hormonic Analysis Technique. Nigerian. J. of Physics; Vol. 24 (www.nipng.org)

17. Ituen, E.U.U., \& Alonge, A.F. (2009).Niger Delta Region of Nigeria, Climate Change and the way Forward. Presentation at the 2009 Bioenergy Engineering Conference Sponsored by ASABE Hyatt Regency Seattle, Washington October 11-14, 2009. Retrieved from elibrary.asabe.org

18. Intergovernmental Panel on Climate, IPCC. (2007). The fourth assessment report (AR4). Climatechange (Synthesis report). Retrieved from http://www.ipcc.ch/publictions_and_data/ar4/syr/en/main.html (Accessed 17th July, 2018).

19. Matthew, O.J., Awotoye, O.O., Dada, A. C., \&Odedokun, O. D., (2013). Regional climate model: Investigating the impacts of climate change on water availability in Nigeria. Scientific Research and Essays, Vol. 8(19), pp. 722 730, 18 May, 2013. Retrieved from http://www.academicjournals.org/SRE.

20. Mmom, C.P., \& Fred-Nwagwu, W. F., (2013). Analysis of Land Use and Land Cover Change around Port Harcourt City, Nigeria. Global Adv. Research J. of Geography and Regional Planning 2(5) 078-086.

21. Odjugo, P.A. Enaruvbe, G.O. \& Isibor, H.O. (2015). Geospatial Approach to Spatio-Temporal Pattern of Urban Growth in Benin City Nigeria. Afri. J. Env. Sci. and Techn. 9(3)166-175

22. Okali, D. \&Eleri., E. O. (2004). Climate Change and Nigeria: A guide for Policy Makers. The publication of the Nigerian Environmental Study Action Team (NEST).

23. Okoro, U.K., Chen, W., Chineke, T.C. \& Nwafor, O.K. (2014). Recent Monsoon Rainfall Characteristics over the Niger Delta Region of Nigeria: A Casual Link. Int. J. Of Sci. Env. And Tech. Vol. 3(2) 634-651. 
24. Ologunorisa, T.E., \&Tersoo, T. (2006). The Changing Rainfall Pattern and its Implications for Flood Frequency in Makurdi. Nigeria. J. Of Applied Sc. And Env. Mgt, 10(3)97-102.

25. Onwuteaka, J. (2014). Predicting Changes in Land Use and Land Cover in Niger Delta using Post Classification Analysis. Civil and Environ. Res. Vol. 6(6), 2225-0514. (www.iiste.org).

26. Stringer, E.T. (1995). Foundation of Climatology (An Introduction to Physical, Dynamic, Synoptic and Geophysical Climatology). Freeman: San Francisco, CA, USA, 1995. Google Scholar

27. Twumasi A. Y., \& Edmund C. M. (2006). GIS and Remote Sensing Applications in the Assessment of Change within a Coastal Environment in the Niger Delta Region of Nigeria. Int. J. Environ. Res. Public Health, 3(1): 98-106.

28. Udosen, C.E. (2012). Rainfall Trends in Uyo-AkwaIbom State and its Implication on Urban Flooding. J. Of Engr. And Applied Sci. Vol. 7(1) 79-85.

29. United Nation, UN. (2015). From MDG's to SDG's, Transforming the World. The 2030 Agenda for Sustainable Development New York United Nations. https://sustainabledevelopment.un.org/accessed 7 July, 2018

30. Yongming Xu, Yan Shen, Ziyue Wu (2013). Spatial and Temporal Variations of Land Surface Temperature over the Tibetan Plateau Based on Harmonic Analysis. Mountain Research and Development, 33(1):85-94 (2013). 